\title{
Saints' Lives and Shoemakers' Holidays: The Gentle Craft and the Wells Cordwainers' Pageant of 1613
}

\begin{abstract}
This essay considers the 1613 Wells Cordwainers' pageant of SS Crispin and Crispianus through an exploration of hagiographical appropriation in two other contemporary iterations of the St Crispin legend and the conditions of English occasional pageantry. A comparison with the prose tale The Gentle Craft by Thomas Deloney and the stage play A Shoemaker, A Gentleman by William Rowley indicates that the Cordwainers improvised on a popular Jacobean version of their patron saints as romance heroes instead of holy martyrs.
\end{abstract}

On Friday, 20 August 1613 the Cordwainers of Wells presented a pageant of SS Crispin and Crispianus to entertain Anna of Denmark, the wife of James I. The queen's visit is recorded in the Wells Corporation Act Book and the Cordwainers' Account Book, both of which are excerpted in Records of Early English Drama: Somerset, including Bath and Wells. These records provide little information about the narrative and kind of theatrical representation that occurred, but from the description of the pageant, cast list, and costume notes it is clear that the Cordwainers presented a drastically modified version of the patron saints of shoemakers. According to the Corporation Act Book the guild 'presented St Crispian \& [blank] both of them sonnes to a kinge and the youngest a shoemaker who married his Masters daughter.'. The Cordwainers' own records document the stage properties and costumes in the guild's possession and that a cast of four actors played the two saints, Lady Ursula, and the nurse to the child of the lady. ${ }^{2}$

This pageant offers a challenging case study in the history of early theatre. What sort of saint play ends with an actual and not a metaphorical wedding instead of martyrdom? How would such a modified saint play represent the characters legibly enough for spectators to know that these four actors were imitating the patron saints of shoemakers? Moreover, why would the Cordwainers have

Gina M. Di Salvo (gdisalvo@utk.edu) is an assistant professor in the department of Theatre at the University of Tennessee. 
presented such an altered version of their patron saints? James Stokes, the editor of REED: Somerset, has suggested that given 'the suppression of religious plays and the political and religious climate in England at that time, it seems unlikely that the Cordwainers would, or could, have presented a pure saints' play. More probably they presented a modified saints' play, perhaps something ... emphasizing the "history" of their craft and the English connections in that history'. ${ }^{3}$ This essay examines the appropriation of hagiography in two versions of the Crispin story in order to further explore the Cordwainers' modification of the St Crispin story from martyrdom into romance. Both The Gentle Craft (1597) by Thomas Deloney and A Shoemaker, A Gentleman (ca 1618) by William Rowley present Crispianus as a military hero and Crispin as the secret lover and eventual husband of Ursula amidst the Roman invasion of an ancient Britain full of kind and loyal shoemakers. In order to better understand the Cordwainers' pageant, I consider how Deloney and Rowley reworked the vitae of SS Crispin and Crispianus into separate romances. These three extant iterations of the St Crispin story offer a rare opportunity in early theatrical historiography to compare across genres, performance locations, and archival records, and to do so without privileging the printed quarto of the professional play over and above the Cordwainers' Account Book that now rests in the Somerset Record Office in Taunton. Because I propose that we view the Cordwainers' pageant as one of multiple 'scripts' of the St Crispin story that circulated in late Elizabethan and Jacobean England, I have organized this essay so that the two fully narrativized versions precede my analysis of the non-scripted records of the pageant. Deloney's prose tale and Rowley's stage play both deviate from sacred versions. Deloney's adaptation, however, attempts to excise traditional aspects of hagiography while Rowley fully embraces a sanctity grounded in British history and geography. In the final part of this essay I return to the 1613 pageants in Wells and examine the records of the Cordwainers' 'historie of Krispie and Krispianie' in light of the two other adaptations of the St Crispin story and their contrasting treatment of hagiographical elements. Rather than viewing the Cordwainers' romanticized pageant as the consequence of the suppression of traditional religion, I suggest that religious reforms enabled the production of new legends of the saints in the early seventeenth century.

Thomas Deloney borrowed iconic figures from a variety of genres, including romance and hagiography, and refashioned them into heroes that celebrate Britishness and the craft of shoemaking. ${ }^{4}$ The Gentle Craft contains three tales of cobblers and cordwainers that explain the legendary origins of holidays that continued to be associated with the trade of shoemaking in the seventeenth century. In the first tale Sir Hugh dies as a quasi-martyr along with the pious St Winifred 
and bequeaths himself to the cobblers of England as St Hugh's bones. In the second the Kentish princes Crispin and Crispianus hide from an invading tyrant in the workshop of a Faversham shoemaker until a great reconciliation occurs on the night of 25 October. In the final tale the history of Simon Eyre celebrates how a master shoemaker became lord mayor and made Shrove Tuesday a holiday for the apprentices of London. ${ }^{5}$ The Shoemaker's Holiday (1599) by Thomas Dekker preceded Rowley in adapting Deloney's prose legend to celebrate the trade of shoemaking in London. Yet, that more famous play did so without engaging the explicitly hagiographical material in the source narrative. Dekker dramatized the making of a shoemaker's holiday, but not saints' lives. While the story of Simon Eyre was adapted into the popular play The Shoemaker's Holiday and has received exploration elsewhere, the first two stories of The Gentle Craft served as the main source for the Jacobean saint play, A Shoemaker, A Gentleman by William Rowley.

The depiction of Crispin and Crispianus in The Gentle Craft could not be further from the vita of the brother shoemakers. In the prose tale Crispin becomes a military hero and Crispianus impregnates Ursula, a de-sanctified appropriation of the medieval British virgin martyr. Put that way one might think that Deloney, whose works are punctuated with late-Elizabethan anti-Catholicism, purposefully bastardized sacred stories by spinning the leftovers of English medieval piety into a bawdy tale. Yet the reworking of the stuff of saints' lives in The Gentle Craft - characters, scenarios, geography, iconography, nationality, patronage, feast days, and chronological period - are too far removed from their original forms to accomplish a burlesque of the sacred genre. Instead, Deloney took Crispin, Crispianus, and Ursula, three historically British-identified saints, out of the pages and contexts of hagiography and reformed them into a romance fit for a shoemakers' holiday.

Deloney's tale of Crispin and Crispianus absents the context, tropes, and imagery of Christian martyrdom. Unlike the adaptive process used in the first tale of The Gentle Craft, which features a modified yet martyred SS Hugh and Winifred and will be discussed below, this one uses hagiography only as raw material for romance. Traditionally the brother saints flee their noble family home to escape 'the furyous persecucion of Crysten men vnder Dyoclesyan and maxymyan'. ${ }^{6}$ They arrive in Soissons where they evangelize and serve the poor, learn the trade of shoemaking to finance their mission, and undergo a series of torments before earning the crown of martyrdom. Deloney commences his own tale of the patron saints of English shoemakers by providing protagonists, an antagonist, a conflict, and a setting typical of martyrdom: 'When the Roman 
Maximinus sought in cruell sort, to bereave this Land of all her noble youth or youth of noble blood, The vertuous Queen of Logria (which now is called Kent) dwelling in the city Durovernum, alias Canterbury, or the Court of Kentishmen, having at that time two young Sons, sought all the means she could possible to keep them out of the Tyrants claws. ${ }^{7}$ But a requirement of martyrdom is missing from this exposition of the plot - there is no persecution of Christians. The Romans aim to arrest the Kentish princes, 'make them slaves in a forraign Land', and 'plant strangers in their stead' in order to consolidate the rule of Britain under a single Roman colonial government. ${ }^{8}$ The brothers disguise themselves in 'homelie garments' and find safe hiding with a Faversham shoemaker and his wife. ' There they become apprentices to the trade and take the names Crispin and Crispianus.

The brother shoemakers ultimately earn their freedom and are restored to aristocracy through martial and marital reconciliation, both of which culminate in the creation of a feast day. While Crispin secretly marries and impregnates Maximinus's daughter, Crispianus is conscripted into the military and sent on a campaign to conquer Roman Gaul and free it from the invasion of the Persians. When Crispianus returns home to Britain he is honored by Maximinus and Crispin, Ursula, and their child are reconciled with the emperor because Crispin is revealed to be the brother of the noble shoemaker-soldier. The reunification of the non-martyred brothers and the open proclamation of the marriage of Crispin and Ursula are cause for special celebration. On that day

the shoomakers in the same town made holiday ... And ever after upon that day at night, the shoemakers make great cheare and feasting in remembrance of these two princely brethren. And because it might not be forgotten, they caused their names to be placed in the kalender for yearly remembrance; which you shall find in the moneth of October about three days before the feast of Simon and Jude. ${ }^{10}$

By concluding the new legend of Crispin and Crispianus with this particular revision of the calendar of Christian saints Deloney reveals one part of his methodology for adapting hagiography in The Gentle Craft, a process that we should consider because it might either parallel or influence the Wells Cordwainers' pageant. Deloney dropped the martyrdom scenario in order to create a romance by taking popular British saints from The Golden Legend as a character, icon, and situation sourcebook and he chose two vitae that are joined by the order of the liturgical calendar. 
The revised Ursula lacks nearly all associations with the legend of 'St Ursula and the 11,000 Virgins', including the voyage from ancient Britain with her thousands of maiden companions and their martyrdom at the hands of Hun arrowmen. The saint offers no connection to shoemakers and her iconographic companion is the arrow that accomplishes her martyrdom, an object that defies exploitation for the celebration of cobblers and cordwainers. What Ursula did offer Deloney is the ease of her calendrical proximity to the shoemaker saints in legendaries. Ursula's feast day falls on 21 October and is the liturgical observation that immediately precedes the feast of Crispin and Crispianus on 25 October. In large legendaries like The Golden Legend the saints appear side by side on the pages, creating an association that Deloney drew from even as he scraped off the context of martyrdom and wrote over it with romance.

The records of the Wells Cordwainers' pageant and Deloney's novel appropriation of the St Crispin story both include a Crispin, a Crispianus, an Ursula, a nurse, and a baby. Additionally, in both tales Ursula marries one of the saints. Although we do not know if the Cordwainers' pageant stemmed from The Gentle Craft, whether directly from the prose legend or through circulation in the oral tradition, the modifications to and merging of the St Crispin and St Ursula stories are a significant common factor. Because of these similar alterations to the saints' legends, we might be led to suppose that the post-Reformation romance appropriation of saints' lives also indicates an absenting of hagiographical motifs. That is, because Deloney's adaptation represented a secularizing romance instead of a sanctifying martyrdom and because the Cordwainers also presented a romance, then they must also have absented hagiographical contexts from their pageant. Two other texts offer a counterpoint to this logic, however, the first tale in The Gentle Craft and William Rowley's stage play based on Deloney's work.

'The Pleasant History of S. Hugh', the first tale in The Gentle Craft, indicates that it was possible to retain the genre of martyrdom even as the craft of shoemaking came to be valued over traditional commemoration of sanctity. The new legend alters the medieval vitae of SS Hugh and Winifred, but unlike the appropriation of hagiography in the St Crispin tale, which excludes the context of martyrdom, this modified saint story includes religious meaning. This first tale of The Gentle Craft denigrates pre-Reformation monastic spirituality, constructs generic martyrdom out of Winifred's unusual life, and relocates both saints from two distinct medieval periods and locations to a singular early medieval Wales, all in the service of assembling a narrative that primarily explains the origins of ' $\mathrm{St}$ Hugh's Bones' - and not the ones that currently lie in the sepulcher at Lincoln Cathedral. 
In Winifred's traditional life a prince attempts rape, fails, decapitates her, and a well springs up from where her head falls. ${ }^{11}$ A priest puts her head back on her body and she miraculously resurrects as the ground swallows her assailant to Hell. Later she founds a monastery and dies a holy death. In contrast to this out-oforder Celtic vita that takes place in the Middle Ages, Deloney places his virgin into a scenario likened to the 'dayes of Dioclesian' and enlists a generic tyrant to persecute her. ${ }^{12}$ Although he positions Winifred at her iconic Welsh well, Deloney reorganizes her life to fit the anticipated structure of ancient virgin martyrdom in which religious devotion precedes martyrdom. ${ }^{13}$ Unlike Winifred, Sir Hugh does not at all resemble his sainted source. St Hugh was a twelfth-century French-born Carthusian monk who eventually became the bishop of Lincoln and in the pages of The Gentle Craft he is a lovesick knight. ${ }^{14}$

The 'Pleasant History of S. Hugh' and 'his most constant love to / The fair Virgin Winifred' attacks traditional observances of religious life and emphasizes martyrdom as the central element of sanctity. After Winifred 'received the Christian Faith' Deloney narrates that she 'became so superstitious ... wherefore forsaking all manner of earthly pomp, she lived a long time very poor ... by the side of a most pleasant springing Well'.15 The description of Winifred's improvised monastic life of chastity, poverty, and prayer as 'superstitious' separates this legend from traditional saints' lives. Rather than serve as an example of virtue and holy intercession for other Christians, this post-Reformation tale explains hermitic virginity as the product of an excessive indulgence in piety and deploys the term 'superstitious' to categorize her pursuit of holiness as papist.

Winifred's reconfiguration includes a more straightforward narrative trajectory. Instead of relying on the motivations of a crazed rapist to accomplish martyrdom, Deloney creates a Sir Hugh who eventually sublimates his erotic desire for the consecrated virgin into a bond of Christian love. Their martyrdom occurs 'as it fell out in the dayes of Dioclesian, that with bloudy minds persecuted such as would not yeeld to the Pagan law: amongst which the Virgin Winifred was one, who for that she continued constant in faith, was long imprisoned'. ${ }^{16}$ Hugh is jailed as a consequence of praising Winifred for 'her faith and constancy' and the two are soon sentenced to death. ${ }^{17}$ The pagan tyrant resembles the provosts and presidents who ruled under Diocletian and fill the pages of the Golden Legend and Foxe's Book of Martyrs. Unlike in other martyrological passions, Winifred and Hugh do not debate their foe, nor do they undergo torture or perform miracles as prelude to their execution. In fact whereas the epigrammatic description of a true martyr, 'non poena sed causa', guides the testimonies of faith in traditional martyrology, both Catholic and Protestant, Deloney's martyrs appear to earn their 
crowns by their gruesome and poetic methods of death at least as much as their profession of Christianity.

The inventive execution of the pair at St Winifred's well develops martyrological motifs that are absent elsewhere in The Gentle Craft. The martyrs are described in terms of imitatio Christi, noting that they go to their execution with the obligatory phrase 'like two meeke Lambs ... led to the slaughter' and Winifred's embrace of her death appears as nuptial solemnity, 'as if she had ben a fair young Bride prepared for marriage'. ${ }^{18}$ Winifred is executed by bleeding and she is 'pricked in every vain, the scarlet blood sprung out in plentifull sort, much like a precious fountain lately filled with Claret Wine'. ${ }^{19}$ In her dying, then, Winifred imitates the holy well that appeared as a miraculous sign of God's affection for her, Christ's crucifixion, and her blood becomes sacred in its reference to sacramental wine. She dies 'like a Conduit suddenly drawn drie' and her blood is gathered in a cup, poisoned, and given to Hugh. Having 'fully gorged' himself on Winifred in his dying, Hugh finds solace that Winifred's 'heart blood ... that nourished her chaste life' will act as a final 'caudle to cool' his 'vain affections'. ${ }^{20}$ Before consuming the last of the blood Hugh toasts 'all the kind Yeomen of the Gentle Craft', the shoemakers who were charitable to him while he awaited his execution, and offers them his bones. ${ }^{21}$ The consumption of Winifred's blood and the sacrifice of Hugh's bones adds a sacramental dimension to knight's death as well as the virgin's. The two become known as St Winifred and St Hugh, 'by which termes they are both so called to this day. ${ }^{2}$

The posthumous memorialization of the two saints splits into static and dynamic cults, respectively. The Welsh shoemakers prefer to commemorate Hugh through spontaneous, ephemeral, and social practices such as celebrating, singing, and working rather than through methods of archiving, such as composing hagiography, building monuments, or paying for a charter proclaiming them The Guild of St Hugh. The virgin is simply buried and forgotten at St Winifred's well whereas the shoemakers 'steal Saint Hughes bones away' and 'make divers of our Tools with them', thus transforming what could have been devotional relics into means of industry. ${ }^{23}$ In composing this story of how Hugh the martyr became the patron saint of shoemakers Deloney nonetheless undermines the traditional and institutional means through which the church commemorates, venerates, and canonizes saints.

This examination of Deloney's modified saints' lives demonstrates that the appropriation of vitae could retain or reject elements of sanctity. If the preceding analysis had been confined to the Crispin and Crispianus tale alone, then we might be led to propose that the only available mechanism for romancing saints 
into the heroes of shoemakers' holidays entails the erasure of hagiographic contexts, narratives, and motifs other than calendrical significance. This assessment might influence how we approach the 'historie of Krispie and Krispianie'. That is, because the Cordwainers' pageant appears to approximate the second tale of The Gentle Craft in terms of the cast of characters and a marriage plot, then we might also reason that the Cordwainers replicated Deloney's organizational principles and necessarily jettisoned martyrological passion and sacrifice. Including the tale of Hugh and Winifred in this analysis, however, considers an alternative dramaturgy for the Cordwainers' adoption of a new legend of Crispin and Crispianus. The guild may have absented hagiographical contexts altogether, as in the second tale, or they may have altered and revised martyrological elements, as in the first.

While no rehearsal notes exist to indicate if the 'Whole historie of Krispie and Krispianie' replicated the strict separation of romance and hagiography in the second tale of The Gentle Craft or if it combined the two as in the first tale of Hugh and Winifred, there is one final extant work from the period that featured a new romance of Crispin and Crispianus. Jacobean playwright William Rowley adapted the first two stories of The Gentle Craft into a single narrative that placed miracles and martyrdom on the same stage as wedlock and warfare. A Shoemaker, A Gentleman offers yet another model of how saints' lives could be revised as they were transformed into the creation myths of shoemakers' holidays. Rowley specifically reinserted the sort of hagiographical values and motifs that Deloney excised in the second tale of Crispin and Crispianus and drastically altered in the first tale of Hugh and Winifred. The play created an ideal saint play for shoemakers' holidays by placing Hugh, Winifred, Crispin, and Crispianus in Roman Britain during a time of Christian persecution and added England's protomartyrs to the plot, Alban and Amphiabel. Shoemaker shows that a new romance could absorb the old gests and sacred stories of traditional hagiography.

While The Gentle Craft, first published in 1597, could have influenced or served as a source text for the Wells' Cordwainers pageant of 'Krispie and Krispianie', Rowley's play succeeds the 1613 pageant by approximately seven years. The inclusion of Shoemaker in the present essay is not meant to suggest that Rowley's dramatic adaptation of Deloney's prose affected the Cordwainers' pageant, which would be anachronistic (or even that the 1613 pageant for the queen affected the ca 1618 stage play). My purpose in examining Shoemaker's treatment of hagiographical elements surrounding the St Crispin story is to further open up the adaptive possibilities for the Cordwainers' pageant. Rowley's revisions to Deloney demonstrate that a romanticized narrative could be taken up without 
also adopting an anti-Catholic position and its consequential denigration of traditional hagiography.

Shoemaker opens to the sounds of warring Romans conquering the ancient Britons and when 'Maximinus and Dioclesian' are named as the perpetrators of the violence in the first scene it becomes clear that the conflict between Rome and ancient Britain is no normal campaign of colonial expansion. Not only does this version of 'The Gentle Craft' place all characters into a plot of Christian persecution in which 'Barbarous Romans' put 'to sword, and torture all, that beare the / Name of Christians' but also Rowley rejects Deloney's perspective on traditional religion and the more legendary aspects of saints' lives. ${ }^{24}$ Even as Rowley retained The Gentle Craft's modified lives he reinserted the markers of hagiography that Deloney excised or dismissed as 'superstitious'.

The context of Christian persecution coupled with the celebration of British shoemakers produces a long history in which Britain is and always has been a Christian nation. In fact the brother princes specifically seek refuge with shoemakers in Rowley's play because the native craftsmen are all secret Christians. This dramatic version of the romance of Crispin and Crispianus creates a strong link between the common populations of ancient Britain and that of contemporary audiences in Jacobean England. Although the majority of the play concentrates on the wooing and warfare of the brother shoemakers, the validation of traditional religion and hagiography emerges in the linked subplots of Hugh and Winifred and Alban and Amphiabel. Rowley does not revert back to Hugh and Winifred's medieval vitae, yet Shoemaker's depiction of these saints rejects Deloney's handling of hagiography.

Instead of denigrating Winifred's improvised monastic life as 'superstitious', Rowley verifies the truth of her virginal sanctity through miraculous theatricality. Wearing a nun's black veil that is referred to as a 'cloister habit' Winifred states she is resolute in her chastity and directs Amphiabel, her confessor, to observe 'what Heaven hath done' and shows him St Winifred's well (C4r). She points to a space on stage that signifies the well, music plays, and 'an Angell ascends out of the Well', gives Amphiabel a 'sign that holy Christians weare', blesses the spring, and recounts its healing powers (C4r). The miraculous proof of Winifred's virginal sanctity propels Amphiabel into action for the cause of Christianity. Before the miracle at the well the priest embraced secrecy and hiding but afterwards he resolves to leave Holywell and travel 'straight ... to the face of persecuting Albon' (C4r). Once converted, Alban receives the 'Embleme of a Christian' that the angel bestowed upon Amphiabel during the miracle at the well (D2v). The cross that Alban wears, 'the daring Badge of Christianity', visually announces his 
conversion to Maximinus (D3r). The Emperor rages and sends soldiers to Holywell after Amphiabel and Winifred, ordering them to

lay desolate the confines of that superstitious

Virgin, that with her sorcerous devotion works miracles,

By which she drawes Christians, faster than we can kill 'em. (D3v)

The tyrant's ire is not misdirected. The spread of Christianity can be directly traced through the symbolic transfer of the miraculous cross from the virgin's angel to Amphiabel to Alban. Furthermore, the accusation of superstition now comes from the mouth of a pagan. Although Winifred's part in this stage version of 'The Gentle Craft' is relatively small, she acts as the catalyst for the victorious establishment of Christianity in ancient Britain. Her role in this conversion contains the stuff of superstition according to both Maximinus's and Deloney's narration.

Winifred performs a second miracle at the well in a scene that triggers martyrdom. The saint reiterates that she is 'contract and wedded to Christ' and that angels sing 'Chast Hallelujahs ... to the celebration of' her 'Virgin rights' (E3r-v). As soon as she proclaims that she is ready and willing to die in 'the Militant Field of Martyrdom' Roman soldiers storm the stage (E3r). The virgin cautions them not to threaten her at the site of her miraculous well:

... tyrant, this place is hallowed; doe not awake the thunder, if it strike, the boult will fall downe Perpendicular, and strike thee under mercy.

In spite of her warning the officer in charge mocks her 'Virgin water' and Winifred responds to disbelief, as in the first scene at the well, with outward proof. She declares 'Doe, play with Lightning till it blasts thee' and instantly one of the officer's men is blind and raving 'Guide me to the divill' (E4v). But the virgin intercedes on the behalf of her blind persecutor with the miraculous speech act, 'By helpe of heaven thus I thine eyes restore', and returns his eyesight (E4v). ${ }^{25}$ Having proved the power of Christianity over her Roman pagan adversaries, Winifred and Hugh, her consummate companion, are taken to Verulamium for execution, the site of Alban and Amphiabel's death in their traditional vitae. There, Hugh and Winifred die in the play as they do in prose, with the virgin bleeding and her 'earthly love' (H4v) drinking her poisoned blood after he honors the shoemakers with a final toast (I1v).

Notably, Rowley keeps Deloney's method of the death for the companionate martyrs but the depiction of sacrifice resembles the saints of medieval legendaries. 
There is no extended meditation on Winifred's bleeding as both imitation of the well and of Christ because Rowley has indulged hagiography each time Winifred appears on stage. The virgin, who has already proven to have the power to bring down angels, sees a vision of them running 'to meet and welcome / me unto the Land of blisse / Singing I have spunne a golden thred' as her life leaves her body (H4v-I1r). Whereas Deloney toiled to depict a post-Reformation martyrdom that included tropes of Christian sacrifice but lacked miraculous conventions, Rowley scripted a generic virgin martyr's life and death.

Rowley's adaptation of The Gentle Craft for the stage demonstrates the staying power of the modified narratives of Crispin and Crispianus and Hugh and Winifred, even as the first pair were Christianized, the second were re-sainted, and a third pair of English saints were added to the plot without modification to their legend. Although Rowley invented Winifred's role in Amphiabel's conversion of Alban, the majority of the protomartyrs' story is lifted directly and without revision from the pages of saints' lives. Scholars have recognized that Rowley used Book IV of Holinshed's Chronicles for the Alban-Amphiabel plot, but Holinshed leaves out a particularly gruesome detail that appears in Maximinus's condemnation of Amphiabel in the play: 26

This fiend Amphiabel, from whose damn'd teat

He suck'd this poison, shall there be bound

By a fixed stake, to which nail'd fast,

The navel of his belly being open'd,

Then with your sword prick him, and force him run

About like a wheel, till he has spun his guts out:

And that dispatch'd, saw off his traitorous head.

$(\mathrm{H} 3 \mathrm{v}-\mathrm{H} 4 \mathrm{r})$

Although many Jacobean playwrights had a gift for the composition of creatively macabre deaths, this specific method of execution, in which the condemned man is forced to disembowel himself by winding around a stake, can only be classified as medieval - not in the pejorative sense, but because the detail appears in John Lydgate's Life of Saint Alban and Amphiabel, the South English Legendary, and The Golden Legend. ${ }^{27}$ The retention of Alban and Amphiabel's traditional vita in addition to the insertion of miraculous virginity, nuptial allusions, and religious veneration reveals that Rowley rejected Deloney's perspective on traditional hagiography even as he maintained the main narrative threads of the first and second tales of The Gentle Craft.

Rowley's dramatic version of the 'The Gentle Craft' suggests that a romanticized version of the St Crispin story could function alongside traditional aspects 
of hagiography, such as sexual celibacy and martyrdom. Shoemaker also cautions against attributing alterations of vitae to or entirely to reformed religious ideology alone. Deloney's prose contains minor but very real declarations against 'superstitious' religion and at least some of the modifications to the legends of the saints can be linked to his anti-Catholicism. Rowley's play, in contrast, embraces the traditional miracles and martyrdom of medieval hagiography. This particular aspect of theatrical adaptation likely had less to do with Rowley's religious position than it did with the Jacobean dramatic repertoire. Shoemaker appeared among a small cluster of Red Bull saint plays and Rowley's other dramatic works favored dumb shows, devils, and otherworldly theatricality. ${ }^{28}$ Rowley built a play out of Deloney's prose and made it suitable for his audiences at the Red Bull where, as Mark Bayer has shown, they expected a celebration of nationalism and spectacular effects. ${ }^{29}$ The conditions of the Red Bull's repertoire provided an opportunity for Rowley to adopt Deloney's legends of shoemakers' holidays without reproducing its assault on saints' lives.

Just as the theatrical repertoire of Jacobean drama is a useful context for Rowley's dramatization of the St Crispin story, so too are the conditions of English occasional pageantry for the Wells Cordwainers' pageant. In 1613 the craftsmen of Wells mounted the following spectacles over six shows for Queen Anna: Noah and the Ark, Vulcan at the forge, Venus and Cupid, virgins wearing hides and horns in a chariot drawn by men in similar attire, St Clement with a friar, SS Crispin and Crispianus, Salome and John the Baptist, two ancient giants, St George and the dragon, and Acteon and Diana. ${ }^{30}$ This juxtaposition of hagiography, mythology, and British folklore in the Wells pageants is representative of the standard hodgepodge of English pageantry. For example, in the fifteenth century the Paston household held an annual St George event that featured 'Seynt Jorge and Robin hod and the Shryff off Notyngham', an unlikely combination for a pious commemoration of St George's death as a martyr. ${ }^{31}$ The 1519 Skinners London Midsummer Watch pageant of St Thomas Becket featured both an erotic romance plot in the holy land and the saint's assassination at Canterbury. In the vita found in the South English Legendary and Caxton's Golden Legend the father of Thomas leaves England for pilgrimage to the holy land, is taken prisoner by pagans, falls in love with the emperor's daughter, converts her, and flees with her back to England. The Skinners' pageant cast includes a 'Sowden,' (Soldan / Sultan), Jewess, and Gaoler, referring to the pagan emperor, princess, and the man who took the elder Becket hostage. ${ }^{32}$ These pageants foreground two important aspects of how saints were depicted in English pageantry. Saints could be and were juxtaposed with and among non-religious elements. Furthermore, popular 
elements of hagiography usually dominated the representation. The city of Wells held on to this custom of mixing saints with other stories and mimetically representing popular, rather than pious, elements of saints' lives.

In addition to the Cordwainers' pageant of Crispin and Crispianus, the Wells guilds presented three saintly spectacles alongside classical gods and morris dancers. These shows represented moments of the saints' vitae, some of which derive from the more legendary parts of medieval vernacular hagiography rather than from accounts in ancient martyrologies or The New Testament. The third show for Queen Anna, produced by the Tanners, Chandlers, and Butchers, included 'St Clement their Saint rode allsoe with his booke And his ffrier rode allsoe who dealt his almes out of his Masters Bagge which hee carried verie full of graynes verie plentifullie'. 33 The Taylors, who were responsible for the fifth show, performed 'Herod and Herodias and the daughter of Herodias who daunced for St Iohn the Baptistes hedd. St Iohn Baptiste beheaded'. ${ }^{34}$ Finally, the sixth and final show included 'King Ptolomeus with his Queene $\&$ daughter which was to bee devoured of the dragon. St George with his knightes who slew the dragon and rescued the virgin'. ${ }^{35}$ Absent from these scenarios are Clement's execution at sea, John's baptism of Christ, and George's torture on a spiked wheel, all of which are notable moments in the vitae that account for the sanctity of the saints. The descriptions suggest that the pageants followed the normal custom and did not present the entirety of the saints' vitae. Rather than represent St George's martyrdom the Mercers depicted an episode that appears in some of George's vitae and they made it particularly spectacular by adding an abundance of supporting characters. The Mercers had presented the pageant in 1607 as part of the infamous church ale that culminated in the Star Chamber lawsuit, Hole v. White. The records of that trial offer a great deal of information about this pageant. The Mercers' show began with 'ffoure gallant knightese two of a side before the Egipt kinge did ryde eight Irish footemen pages were attndinge on the king' followed by a 'fyrye Dragon lay in wayt for to devoure the princesse straight' before St George appeared with 'his knightes' and 'wrought the dragons great decaye \& saved the prynces lyfe that day'. ${ }^{36}$ This pageant of King Ptoleomeus's Egyptian court represented an exotic romance of St George slaying the dragon and saving the maiden.

The guilds of Wells upheld the English custom to portray iconic and popular moments of saints' lives in pageantry. The presentations of SS Clement, John the Baptist, and George eschewed elements of mortification, miracles, and martyrdom. The shows instead excerpted and elaborated on festive (Clement), erotic (John the Baptist), and chivalric (George) moments from the legends of saints. 
These conditions of pageantry in Wells provide a framework for the interpretation of the records of the Cordwainers' pageant. In the original legend of SS Crispin and Crispianus the brother shoemakers work at night in order to perform Christian charity. They mend the soles of the poor and raise funds with their labor to give alms while they evangelize during the day. The saints are later tortured and executed. In the records of the pageant there is no mention of missionary efforts or of martyrdom, but given how pageant makers in Wells depicted saints and other figures, we should not be surprised by this particular absence - if it ought to be considered an absence at all. The martyrdom of SS Crispin and Crispianus is not any more absent from the Cordwainers' pageant than was the martyrdom of St George from the Mercers'. And, yet, while it is not surprising that the guild did not seem to have depicted the vita, it is surprising that they seem to have represented another narrative altogether. In other words, even though a notable part of the John the Baptist pageant was Salome's dance, the records do not indicate that Christ's saintly cousin married Herod's daughter, which is the comparative modification made to the St Crispin story.

The Wells Corporation Act Book documents 'The Cordyners who presented St Crispin \& (blank) both of them sonnes to a kinge and the youngest a shoemaker who married his Masters daughter they allsoe presented a morrice daunce and a Streamer with their armes'. ${ }^{37}$ The Cordwainers' own records match those of the city although they include a more specific order of ceremony. The guild recorded that 'The whole historie of Krispie and Krispianie was shovne' for the queen on 'the twentye day of avgvste 1613'.38 The entertainment began with a procession of the master shoemakers and a presentation of 'the shovmakers arms', 'the streamer', and 'the Gilley laste', that is, their arms, a banner, and 'a foot-shaped model and a shoe' affixed to a staff. ${ }^{39}$ This was followed by the pageant of Crispin and Crispianus and the entire entertainment concluded with a morris dance, an element in a number of the shows for Queen Anna. The guild recorded a cast list and a full inventory of the pageant, which I quote in its entirety below:

Iohn Eddicott beinge Crispieanus and Iohn Ions beinge Crispian being both shovmakers svnes and the ladie vssile being marthae hvnte a shovmakers dafter and marie bvkstone beinge nvrs vnto the lady vssilies Childe being a shovmakers daster and all those parsons made a moste famos shove $\&$ it was well liked withe all

The vinintorie of The goods is

The ladis vrssilis Crovne

The master shovmakers stafe $\&$ arms 
The streamer and stafe and the Gilley leste and stafe Crispine

briches and Iackett \& Crispianvs Iackett and one Gorgett

and $\mathrm{v}$ Iacketes for five footmen. ${ }^{40}$

The properties, cast list, and descriptions of the 1613 pageant for Queen Anna leave traces of 'The Gentle Craft', by which I do not mean Deloney's specific text of The Gentle Craft so much as an altered and romanticized version of the Crispin story that circulated in the Jacobean era in which one of the saints marries the daughter of a 'master' and the saints do not undergo martyrdom.

The Cordwainers likely presented 'The Gentle Craft' version of the St Crispin story for the first time in $1613 .{ }^{41}$ The guild did not present a pageant during the 1607 festivities documented in Hole v. White and, unlike companies such as the Mercers, they did not have a recent show to remount. Often a company accounted for expenditures related to the 'repairing' of a pageant, but the Cordwainer's Account Book indicates that they built theirs from scratch. The guild spent nearly all of their available funds on the pageant and 'Only $10 \mathrm{~s}$. $10 \mathrm{~d}$. remained in the accounts' after the queen's visit. ${ }^{42}$ They might have jettisoned a traditional show depicting part of the vita of SS Crispin and Crispianus or they might have been in the habit of simply presenting their arms but 1613 is the only recorded date for the premiere of the Wells Cordwainers' production of 'The Gentle Craft'. Although it is possible that the guild took up a romanticized version of their patron saints prior to Queen Anna's visit to the city, the pageant property known as 'lady vrssilis Crowne' does not appear in the Cordwainers' Account Book before 1613. To be clear, I am not arguing that the guild was not in possession of a crown before the queen's visit. I am arguing specifically that they did not have a crown that belonged to St Crispin's pregnant wife until that event.

The novel inclusion of Lady Ursula opens up some final considerations for the 1613 pageant for Queen Anna. A major difference between Deloney's and the Cordwainers' pageant might exist in the matter of Crispin's 'master.' In The Gentle Craft, Crispin and Crispianus take refuge with a Kentish shoemaker, who becomes the master to whom they are apprenticed. Crispin, who remains at the shop in Kent while his brother is conscripted into military service, marries Ursula, the daughter of the Emperor Maximinus. If the Cordwainers were improvising on the St Crispin story, similarly to Deloney, then the 'master' might actually refer to Maximinus. Yet, the records make no mention of the persecuting Roman emperor who looms large in the prose tale as well as in Rowley's tragicomedy. Or, the Cordwainers' pageant that 'presented St Crispin ... a shoemaker who married his Masters daughter' might have represented an alternative 'The Gentle Craft', 
in which Crispianus goes to war wearing a gorget and Crispin clandestinely marries the master shoemaker's daughter. Ursula would have later received a crown, a significant property in the guild's inventory, due to Crispin's royal status rather than her own. This is all supposition, of course, but I offer these other 'scripts' of 'The Gentle Craft' based on a comparison of the records of the pageant to Deloney and Rowley.

The queen's presence offered the city's guildsmen a unique opportunity to restage the shows from 1607 that the reformed masters of Wells had then opposed. 43 The city also put forth two new pageants: one of St John the Baptist and some version of SS Crispin and Crispianus that seems to resemble 'The Gentle Craft'. If ever there were an occasion to revert back to a more traditional depiction of the patron saints of shoemakers in post-Reformation Wells, then it would have been on the Catholic queen's visit. Yet, the romanticization of these former martyrs specifically allowed for the depiction of royal marriage and queenship. St Ursula notably appeared in a pageant for Katherine of Aragon on London Bridge in 1501. In that pageant the virgin martyr alluded to her ancient British heritage and linked it to the legendary King Arthur, a figure of royal authority whom the Tudors had adopted as their own royal ancestor. The saint told the Spanish princess that just as her new husband

Succedith the furst Arthure in dignite,

So in lyke wise, Madame Kateryn, yow

As secunde Ursula shall succeed me. ${ }^{44}$

St Ursula performatively anglicizes Katherine, but in her virginal sanctity she does not honor her as queen consort. Katherine's new patron saint would never marry King Arthur, at least not in pre-Reformation England. In her romanticized form in post-Reformation Jacobean Wells, however, the modified Lady Ursula took on a new role as the wife of St Crispin, the son of a king. As a predecessor queen consort the Cordwainers' Ursula had the ability to honor her most important audience member, the wife of the English king.

Given the circulation of 'The Gentle Craft', and the range of religious and secular pageantry presented for Queen Anna in 1613, I would like to consider the romanticized pageant as part of the enabling consequences of religious reforms while also recognizing the Reformation's destructive impact on hagiography and early English theatricality. Although religious reformers were hostile to traditional pastimes, the depositions from the controversial Wells shows of 1607 reveal that there was much more opposition to music and dancing on the sabbath and the planting of a maypole than to guild pageants containing saints and gods. Rather 
than view religious reforms only as a censoring force on theatrical customs and saints' lives, though they certainly were that too, the circulation of 'The Gentle Craft' and the Wells Cordwainers' pageant of 1613 indicates that reforms could also take on an enabling function for producing new legends of the saints. Even though the city of Wells excerpted and improvised on hagiographical and mythological stories, it is unlikely that the romance of Crispin, Crispianus, and Ursula would or could have appeared on those streets a hundred years prior. In 1513 Wynkyn de Worde had just completed the eighth printing of the Golden Legend, a collection that published the lives of the saints as recognized by church, state, and English culture. With such an orthodox hold on the structure of sanctity it is hard to imagine the Wells Cordwainers presenting the story of 'St Crispin's Gone A-Wooing' before the Reformation, even if they wanted to. In 1597 Deloney was able to rewrite the stories of saints precisely because that orthodoxy had been removed and Elizabethan anti-Catholic sentiment authorized the denunciation of traditional sanctity as 'superstitious'. When the Cordwainers presented their pageant in 1613 they also did so in the absence of early sixteenth-century religious orthodoxy, but for a Catholic queen. With the rare opportunity available to them to present 'The whole historie of Krispie and Krispianie' they created a new pageant of 'The Gentle Craft' that could, at once, honor shoemaking, their patron saints, British heritage, and their queen.

\section{Notes}

I gratefully acknowledge the helpful suggestions I received from the anonymous reviewers and editors of Early Theatre. Thanks are also due to Thomas Postlewait, William N. West, and Stephen K. Wright for their encouragement.

1 James Stokes (ed.), REED: Somerset (Toronto, 1996), 1.372.

2 Ibid, 1.377.

3 Ibid.

4 Before completing The Gentle Craft, which was explicitly dedicated to the London Cordwainers, Deloney had composed the prose fiction Jack of Newbury (1597). This work celebrated the history of cloth making in England. The second part of The Gentle Craft was published in 1598 and contains more tales of shoemakers. Unlike the first part, the stories of Long Meg of Westminster, Tom Drum on Fleet Street, and the Greene King of St Martin's do not concentrate on holiday making although holidays and celebrations are featured. 
5 For a more thorough investigation into the association between shoemakers and holiday-making, see Alison A. Chapman, 'Whose Saint Crispin's Day Is It Anyway?: Shoemaking, Holiday Making, and the Politics of Memory in Early Modern England', Renaissance Quarterly 54 (2001), 1467-94.

6 Jacobus de Voragine, Legenda aurea sanctorum, sive, Lombardica historia (1483), Early English Books Online, CCCxxxviii recto. Importantly, SS Crispin and Crispianus came late to English vernacular hagiography and are absent from most legendaries, including the South English Legendary and Nova Legenda Angliae.

7 Thomas Deloney, The Gentle Craft, ed. Simon Barker (Aldershot, 2007), 22.

8 Ibid.

9 Ibid.

10 Ibid, 40 .

11 The basic narrative outline of Winifred's life, defense of virginity, death, resurrection, and monastic life derives from a twelfth century Latin vita composed by Robert, prior of Shrewsbury. See 'The Life and Translation of St Winefride', in Two Mediaeval Lives of Saint Winefride, trans. Ronald Pepin and Hugh Feiss (Toronto, 2000), 22.

12 Deloney, Gentle Craft, 14.

13 In virgin martyr legends, ancient saints such as Katherine, Margaret, Agnes, Cecilia, and Agatha defend their faith and virginity against a Roman official, suffer torture and imprisonment, thwart attempts at rape or spectacular death through miracles, and, finally, die the death of a martyr through beheading. See Karen Winstead, Virgin Martyrs: Legends of Sainthood in the Middle Ages (Ithaca, 1997), 5.

14 Hugh's miracles are not especially spectacular. The Golden Legend does not document any that connect the Bishop of Lincoln with shoemakers, but the Nova Legenda Angliae entry for Hugh includes 'a cordoner [cordwainer] which had great deuocion to Seynt Hughe bysought almyghty God that he myght dye \& go to heuyn with hym, \& so bynge confessyd \& howselyd he dyed fourthwith'. Manfred Gorlach (ed.), The kalendre of the newe legende of Englande edited from Pynson's printed edition, 1516 (Heidelberg, 1994), 117.

15 Deloney, Gentle Craft, 7.

16 Ibid, 14.

17 Ibid, 15.

18 Ibid, 17.

19 Ibid, 18.

20 Ibid, 19.

21 Ibid.

22 Ibid. 
23 Ibid, 20.

24 William Rowley, A Shoo-maker a Gentleman (1638), EEBO, B2v. All subsequent quotations from this play will be taken from this edition and will be referenced parenthetically in the text.

25 Not only are these two miraculous episodes absent from St Winifred's traditional life, but also they combine aspects of recognizable episodes from other virgin martyr legends. The first scene recalls the angelic apparition that validates St Cecilia's claims to consecrated virginity in her legend and the second scene borrows its smiteand-restore structure from the life of St Agnes when demons attack the young man who attempts to rape the saint in the brothel and God restores him to life through her sympathetic prayers.

26 In her edition of Shoemaker, Trudi Darby recognizes Rowley's source for the AlbanAmphiabel plot as Book IV of Holinshed's Chronicles. See A Shoemaker, A Gentleman (London, 2002), ix. The first to note Holinshed's influence was W. Stork, His All's Lost by Lust, and A Shoemaker, a Gentleman (Philadelphia, 1910), 160.

27 Stanley Wells suggests that Rowley 'went back to Caxton's 'Golden Legend', last printed in 1527 ' for his depiction of the Alban-Amphiabel story and, especially, the unique details of the forced self-disembowlment. See his 'William Rowley and 'The Golden Legend', Notes and Queries 6 (1959), 129.

28 The cluster of Red Bull saint plays includes A Shoemaker, A Gentleman (ca 1618), The Virgin Martyr (1620) by Philip Massinger and Thomas Dekker, and the anonymous Two Noble Ladies, and the Converted Conjuror (ca 1619-22). Marta Straznicky, 'The Red Bull Repertory in Print, 1605-60', Early Theatre 9 (2006), 144-56. These later Jacobean plays continued a repertoire of sanctity begun with If You Know Not Me, You Know Nobody, Or The Troubles of Queen Elizabeth, Part I (1605) by Thomas Heywood.

29 Theatre, Community, and Civic Engagement in Jacobean London (Iowa City, 2011) and 'Staging Foxe at the Fortune and the Red Bull', Renaissance and Reformation/ Renaissance et Réforme 27 (2003), 61-94. For more on the Red Bull, see Lucy Munro, 'Governing the Pen to the Capacity of the Stage: Reading the Red Bull and Clerkenwell', Early Theatre 9 (2006), 99-113, http://dx.doi.org/10.12745/et.9.2.732, and, especially, Eva Griffith, A Jacobean Company and Its Playhouse: The Queen's Servants at The Red Bull Theatre, c. 1605-1619 (Cambridge and New York, 2013) https://doi. org/10.1017/CBO9781107323537.

30 Stokes, REED: Somerset, 1.372.

31 Normon Davis (ed.), Paston Letters and Papers of the Fifteenth Century (Oxford, 1971), 1.461 . 
32 Jean Robertson and D.J. Gordon (eds), A Calendar of Dramatic Records in the Books of the Livery Companies of London, 1485-1640 (Oxford, 1954), 4.

33 Stokes, REED: Somerset, 1.372.

34 Ibid.

35 Ibid.

36 Ibid, 1.268 .

37 Ibid, 1.372.

38 Ibid, 1.377.

39 Ibid, 1.377 and James Stokes, 'The Wells Cordwainers Show: New Evidence Concerning Guild Entertainments in Somerset', Comparative Drama 19 (1985-86), 335.

40 Stokes, REED: Somerset, 1.377.

41 Stokes's extensive research into the Wells Cordwainers follows pageant-related expenses in the Account Book through 1642, a date at which the guild's inventory still included a streamer and crown. From this he deduces an 'integral relationship between the parade of arms and the dramatization in the Cordwainers' show. Since the goods were part of the company's permanent stock of playing gear, and nothing in the account suggests the purchase of unique items, the show presented in 1613 seems to have been the Cordwainers' traditional show and play of SS Crispian and Crispianus rather than something new'. See 'The Wells Cordwainers Show', 337.

42 Ibid, 333.

43 For more on the Wells shows of 1607 and the case of Hole v. White see David Underdown, "But the Shows of their Street": Civic Pageantry and Charivari in a Somerset Town, 1607', The Journal of British Studies 50 (2011), 4-23; Carolyn Sale, 'Slanderous Aesthetics and the Woman Writer: The Case of Hole v. White', Peter Holland and Stephen Orgel (eds), From Script to Stage in Early Modern England (Basingstoke and New York, 2004), 181-94; Stokes, 'The Wells Shows of 1607', Meg Twycross (ed.), Festive Drama: Papers from the Sixth Triennial Colloquium of the International Society for the Study of Medieval Theatre, Lancaster, 13-19 July, 1989 (Woodbridge, 1996), 145-56. See also Nadia Van Pelt's examination of the restaging of the 1607 shows for the queen in 1613, 'Enter Queen: Metatheatricality and the Monarch on/ off Stage', Sean McGlynn and Elena Woodacre (eds), The Image and Perception of Monarchy in Medieval and Early Modern Europe (Cambridge, 2014), 298-319.

44 To recall Katherine of Aragon first married Prince Arthur, the eldest son of Henry VII and heir to the throne. Receyt of Ladie Kateryne, ed. and intro. by Gordon Kipling, Eets os 296 (Oxford, 1990), 15. 